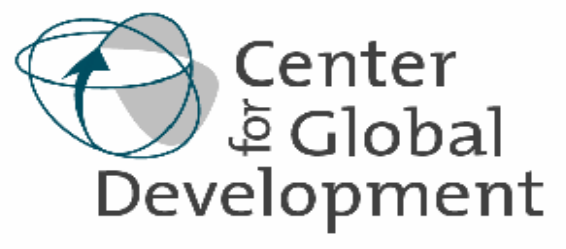

Working Paper Number 50 December 2004 (revised December 2005)

Seven Deadly Sins: Reflections on Donor

Failings

By Nancy Birdsall

\begin{abstract}
In the face of continuing development challenges in the world's poorest countries, there have been new calls throughout the donor community to increase the volume of development aid. Equal attention is needed to reform of the aid business itself, that is, the practices and processes and procedures and politics of aid. This paper sets out the shortcomings of that business on which new research has recently shed light, but which have not been adequately or explicitly incorporated into the donor community's reform agenda. It outlines seven of the worst "sins" or failings of donors, including impatience with institution building, collusion and coordination failures, failure to evaluate the results of their support, and financing that is volatile and unpredictable. It suggests possible short-term practical fixes and notes the need ultimately for more ambitious and structural changes in the overall aid architecture.
\end{abstract}




\title{
Seven Deadly Sins: Reflections on Donor Failings
}

\author{
Nancy Birdsall* \\ Prepared originally for Conference on Emerging Global Economic Order and Developing Countries \\ Bangladesh Economic Association \\ June 28 - July 1, 2004 \\ Dhaka, Bangladesh \\ December 12, 2004 \\ (Revised December 19, 2005) \\ * President, Center for Global Development, Washington D.C. (nbirdsall@cgdev.org). \\ I am enormously grateful to Gunilla Pettersson for her many suggestions on content and \\ concepts, and for timely and cheerful research assistance. I thank, Owen Barder, Stijn \\ Claessens, Peter Isard, Charles Kenny, Steven Knack, Maureen Lewis, Mick Moore, \\ David Roodman and participants in seminars at the Operations Evaluation Department \\ at the World Bank and at the Bangladesh Economics Association for their comments on \\ an earlier draft.
}




\section{Introduction}

The donor community may look back on the 1990s as a watershed. In that decade, some developing countries took off in growth terms, apparently benefiting from and effectively exploiting the increasing integration of the global market. But others, in sub-Saharan Africa, in Latin America and in much of Central Asia, seemed stuck. Many of the countries where growth faltered had been major recipients of development assistance over several decades, and under the tutelage of the donors had implemented structural reforms and thousands of projects. In doing so, some had accumulated substantial debt to multilateral and bilateral creditors, to the point where the donors were engaged in a major effort to write down those debts. For many of the world's poorest countries, the record of development and of development assistance seemed dismal.

As a community, donors responded in the last decade with new efforts to assess their own policies and practices. The end of the Cold War made it possible to imagine ensuring that foreign aid could more directly address fundamental development problems. As a result, there have been not only new calls to increase the volume of development assistance, but new resolutions to reform the process by which assistance is designed and delivered.

In this paper I focus on the "sins" of donors as a community in the hope it will enrich the ongoing discussion of reform of what might be called the "business" of development assistance. I deal with the shortcomings of the donor countries as providers of development assistance, leaving aside in this paper their shortcomings in such other areas as trade, security, and international migration that also affect the developing countries. In referring to donors and the donor community I refer both to bilateral donors and the World Bank, the IMF, and other international institutions that provide credit at below-market rates to developing countries, and whose policies and practices are heavily influenced by the rich countries.

After more than a decade of declines in total foreign aid, commitments on amounts of aid have increased, both in the U.S. and in Europe, so I refer only briefly to the inadequate quantity of aid. Instead I concentrate on problems with the "quality" of aid. The problems with aid quality matter tremendously because research indicates that they reduce considerably the effective value of the aid that is transferred, and in the most aiddependent countries may well mean that the way the "business of aid" is conducted actually undermines those countries' long-term development prospects. The sins I discuss are, in the order in which I address them:

\#1. Impatience (with institution building)

\#2. Envy (collusion and coordination failure)

\#3. Ignorance (failure to evaluate)

\#4. Pride (failure to exit)

\#5. Sloth (pretending participation is sufficient for ownership)

\#6. Greed (unreliable as well as stingy transfers)

\#7. Foolishness (underfunding of global and regional public goods) 
My purpose is not to condemn the donor "sins" but, by being frank and clear about them, to generate a broader conversation among donors, recipients, and the concerned non-official development community, about how they might be addressed. In that spirit, I suggest "fixes” for the sins of donors.

\section{\#1. Impatience with institution building}

Increasingly development theorists are emphasizing the importance of the "software" of an economy: the institutions, customs, laws and social cohesion that help to create and sustain markets for growth and poverty reduction. ${ }^{1}$ Good software can come in many forms, ranging from the European Union's independent central bank to the ingenious Chinese experiment with the village enterprise system. ${ }^{2}$ In some societies it can take less tangible forms, such as the longstanding trust that exists between private contracting Chinese parties that fueled growth in Malaysia. In other societies, it takes the form of legally enforceable property titles and contracts and an uncorrupted court system. Conversely, it is becoming increasingly clear that economies without the right institutions will falter. Poor supervision of banks can lead to financial crises; civil service systems without performance standards and rewards undermine public services; and abuses of property rights discourage the creation of small businesses.

So development can be thought of as a process of creating and sustaining the economic and political institutions that support equitable and sustainable growth. But what about the great majority of developing countries, where political and economic institutions are by definition (as they are developing countries) weak, yet where the poverty and lack of opportunity of millions of people cannot easily be ignored? These include not only the recently failed states, such as Somalia, Afghanistan, Sierra Leone and Liberia, but another 50 or more states that are "weak", "poorly performing" or "under stress". 3 Most of these are low-income (as opposed to middle-income) countries with large proportions of poor people - not surprisingly since by definition they have not got the institutions critical to ensuring sustainable growth.

In the case of failed states, the donors have not generally had patience for the long-term challenge of building new institutions. The example of Haiti, where the donors entered in the mid-1990s with the return of Jean-Bertrand Aristide, only to then exit within a few years, and have now re-entered, is not encouraging. ${ }^{4}$ Nor is the current situation in Afghanistan, where donors are not meeting their pledges of assistance. The evidence is that external financing surges in the first year or two after resolution of a conflict, but then tails off just when it might better be absorbed as institutions begin to take hold. ${ }^{5}$

\footnotetext{
${ }^{1}$ A good example is Acemoglu, Johnson and Robinson, 2004. See also North, 1990.

${ }^{2}$ Rodrik, 2003 cites other examples from China, to help explain its success outside the boundaries of conventional wisdom.

3 The terms are used in, respectively, Commission on Weak and Failing States, 2004; Poor Performers: Basic Approaches for Supporting Development in Difficult Partnerships, 2001; and World Bank Group Work in Low-Income Countries under Stress, 2002.

${ }^{4}$ Weinstein, 2004 argues that in some cases it may be better for the international community to hold off on intervening before countries in conflict have struggled politically toward a new internal equilibrium. Here I am discussing impatience however not with an initial intervention, where the tradeoff with saving lives may be particularly difficult, but with post-conflict development assistance.

${ }^{5}$ Collier and Hoeffler, 2002.
} 
One problem is that aid is budgeted annually in the donor countries while nationbuilding takes predictable and continuous support over many years. In addition, nationbuilding requires spending on high-risk programs such as police and security assistance, the immediate benefits of which are less visible and less attractive politically than humanitarian assistance or reconstruction of infrastructure. ${ }^{6}$

Even less defensible is the limited success of donors over the last three and more decades in supporting institutional development in the many more countries that are not or have not "failed" but are now variously labeled as weak or poorly performing. They are in what might be called the grey zone - with functioning governments but gaps in their legitimacy, their capacity, and/or their ability to maintain security. ${ }^{7}$ In these generally aid-dependent countries (where aid constitutes more than 5 percent of GDP and finances as much as 50 percent of all government spending), donors face the dilemma that aid inflows, including through NGOs, drive up the demand for local skilled people - often competing with the beleaguered government itself; in these settings aid may be counterproductive, undermining rather than strengthening public institutions. $^{8}$

Consider examples of how donor impatience avoids and even undermines the challenge of building institutions.

Impatience for "results" has led to programs and projects in which monitoring focuses on visible short-run inputs (such as purchase of goods and issuing of contracts), and sometimes intermediate outcomes (such as an increase in government spending on social programs). In the best but rare cases the emphasis is on actual results that can be attributed to new programs or inputs financed or inspired by a donor, such as a reduction in infant mortality, an increase in what students are learning in school, or a decline in the cost of transportation due to an adequately maintained road. In general, however, impatience for results leads to reluctance to invest over the long-term (and outside the confines of donor-sponsored programs and projects) in local capacity to do budgeting, personnel management, auditing, accounting, and other nuts and bolts functions - which require and reinforce institutions, but which do not yield obvious immediate results.

Impatience to disburse money and see something happen precludes attention to the fundamental institutional problems, such as political patronage influencing teacher placement in the case of education programs, or vested interests preventing banking sector or judicial sector reforms. ${ }^{9}$ Part of the problem is that bilateral donors work from annual budgeted amounts by their legislatures, and fear that their inability to spend down authorized amounts will be judged as their own ineffectiveness or poor planning. Even the World Bank and the other multilaterals face pressures to meet annual disbursement goals.

\footnotetext{
${ }^{6}$ Greater support for police and other forms of security assistance are included among the recommendations in the report of the Commission on Weak States and U.S. National Security, 2004. See CGD, 2004.

${ }^{7}$ See footnote 3 above.

${ }^{8}$ See Moss, Pettersson, and van de Walle, 2005 and Rajan and Subramanian, 2005.

${ }^{9}$ For all its value, even the recent emphasis of the World Bank and its partners on expenditure monitoring in the context of PRSP programs does not in itself go to the heart of the problem.
} 
Persistence of Project Implementation Units (PIUs). In their impatience to implement "their" projects, donors continue to constitute special units outside of the recipient country governments, as a mechanism to bypass the bureaucratic, salary and other constraints of recipient governments. Research shows that hoped-for better (or faster) results do not outweigh salary distortions and the opportunity cost of failing to ensure that projects and programs are ultimately incorporated into the government's own budgeting, staffing and other institutional arrangement which provide for continuity. ${ }^{10}$

Impatience for policy change leads donors and official creditors to abstract from the political constraints reformers face in their own governments - sometimes undermining the efforts of reformers rather than supporting them. Willful naivete about political reality may help explain why many structural adjustment programs supported by the IMF and the World Bank, and endorsed by the larger donor community, have failed to generate growth (Easterly, 2002a). ${ }^{11}$ In the worst cases, impatience leads to waivers of conditionality altogether, eliding the problem of institutions; the repeated waivers of conditionality regarding taxation of agricultural land (resisted fiercely by large landholders) in World Bank and IMF adjustment loans to Pakistan throughout the 1980s and 1990s are a good illustration. ${ }^{12}$

Institution building has to be local to respond creatively to local constraints and opportunities. Donors can provide financial encouragement for countries to address what Rodrik calls "first-order economic principles" or "functions" such as protection of property rights, appropriate incentives and sound money. ${ }^{13}$ But they have generally failed when they have pushed specific institutional packages for carrying out those functions. The judicial system, the parliamentary rules, the financing of health care that work in one country may not work in another. The failures have inspired the new emphasis of donors on recipient country ownership of their own reform programs, an issue I return to below.

\section{Some donor efforts}

In principle, the more "selective" approach to country support embodied in the Millennium Challenge Account (MCA), and the Country Policy and Institutional Assessment (CPIA) of the World Bank creates an incentive for countries in the grey zone to climb the ladder toward first-order economic and political principles - without dictating the institutional form for doing so. ${ }^{14}$ If fully transparent these measures would catalyze local civil society or legislative or private business pressures for the changes needed to bring greater external assistance - and which may be also key to creating or strengthening critical institutions. But in neither case, is it clear that countries have much leverage on use of resources, nor are the measures as transparent as they could be. ${ }^{15,16}$

\footnotetext{
${ }^{10}$ See World Bank, 2004, pp. 205-206 for examples from Bangladesh and elsewhere and citations to relevant research.

${ }^{11}$ See also Chart 2 from Easterly, 2002a.

${ }^{12}$ For an excellent if depressing analysis of prolonged lending by the IMF, including the story in Pakistan, see IEO, 2002.

${ }^{13}$ See for example Rodrik, 2003 and Rodrik, 2004. See also Hausmann and Rodrik, 2002.

${ }^{14}$ Radelet, 2004 describes the MCA criteria and analyzes their implications for country eligibility.

${ }^{15}$ The MCA criteria are transparent though not the final country choices of the U.S. Government (see Radelet, Lucas, and Bhavnani, 2004). The CPIA is not transparent; the exact quantitative basis for
} 
Also on the positive side, donors are moving in the direction of providing large inflows of budget support (including in the form of debt relief) and sector-wide support for relatively good performers. Time will tell whether donors remain patient with the risk that countries" "performance" will not be sustained or that "results" will be limited in the short run.

\section{A real donor fix?}

But the challenge remains how to help the many developing countries with limited institutional capacity and thus limited ability to absorb large infusions of external aid.

In today's good performers, the use of new delivery mechanisms that are more accordion-like would make sense. These would allow for small initial transfers but build in predictable and automatic increases tied to transparent indicators of increasing absorption capacity. The current 7-year and longer projects supported by the development banks are reasonably good examples. But the banks want to meet disbursement schedules and disburse "on time", when patience to wait out periods of poor performance would ultimately be more effective and less wasteful. Grants to nongovernment groups also make sense, particularly to support the advocacy and training that might create healthy pressure on government to adhere to first principles. An example would be support for groups demanding election reform or campaigning for freedom of the press. And grants to individuals for long-term education and training at home or abroad ought to be resuscitated; after the 1960s, they were abandoned by the U.S. and other aid programs.

Nevertheless, the real fix will only come when the donor community admits how fundamental the challenge is. If institution building in weak states is at the heart of development, then development assistance has to support the creation and strengthening of institutions - a long-term project that requires more predictable aid budgets (discussed below), patience, and the stomach for programs inherently lacking observable short-term performance indicators.

\section{A related reflection on donor impatience and the Millennium Development Goals}

On the positive side, the Millennium Development Goals allow for and invite a relatively long planning horizon. On the negative side, countries that by historical standards are succeeding beyond measure, such as Burkina Faso, Mali and Uganda ${ }^{17}$

\footnotetext{
countries' scores is not published, but only the quintile in which each country falls. The CPIA incorporates a partial measure of "institutions".

${ }^{16}$ The difficulty of measuring "institutions" may explain why there is some inconsistency in the ranking of developing countries across different measures. For example, several countries eliminated from the MCA due to the corruption criterion or insufficiently high rankings on other criteria are in the first or second highest quintile of the CPIA measure (Bangladesh, Albania, Burkina Faso, Mauritania). And of countries ranking in the top two quintiles of the CPIA measure, Vietnam and Pakistan are in the bottom two quintiles of "legitimacy", and Senegal, Mauritania, Burkina Faso and Mali among others are in the bottom two quintiles of "capacity" (see Charts 1A and 1B). In its report on weak states and U.S. national security, the Center for Global Development put countries into quintiles of "legitimacy" based on the Kaufman, Kraay, and Zoido-Lobaton (2002) measure of "voice and accountability", and quintiles of "capacity" based on the immunization rate. See CGD, 2004.

${ }^{17}$ See Clemens, 2004, on education, and Clemens, Kenny and Moss, 2004 on education, infant mortality and other goals.
} 
(see Chart 1C) are currently characterized as "off-track" on such measures as education and infant mortality in UN reports (e.g. the Human Development Report of 2003, which uses a simple linear measure of trends), and unless they can accelerate progress even more dramatically will not meet certain of the goals by 2015. For example, Burkina Faso is "off-track" from meeting the goal of universal primary schooling by 2015 . The net primary enrollment rate was just 35 percent in 2000, and by one estimate (extrapolating from historical experience of more than 100 countries which takes the form of a logistics curve; see Clemens, 2004) would reach "only" 59 percent by 2015. However, compared to the historical performance of today's rich countries, that rate of progress would be impressive. It would roughly match South Korea's progress between about 1945 and 1955, ${ }^{18}$ but far outpace the progress of the U.S., which, starting at Burkina Faso's current enrollment rate of 42 percent, took 30 years to increase its rate to 57 percent (Chart 1D).

Given our limited understanding of how to create and sustain the institutional setting that must complement additional donor transfers to achieve the goals in those countries, the MDGs create the risk that the donor community will succumb (even more) to the distortions that impatience creates. The MDGs should not become a lightning rod around which countries that have been unusually successful (compared to historical trends and given their income and institutional capacity) are, in 2015, characterized as "failures." Better that the MDGs become a lightning rod for ending donor impatience, so that additional donor transfers to the poorest countries can be more explicitly attuned to institution building. Under that arrangement, donors would have to exhibit patience when there are setbacks, and in some cases a willingness to hold back funds. That brings us to the second sin.

\section{\#2. Envy (collusion and coordination failure)}

In contrast to the early days of development assistance, when for example the U.S. was the dominant donor (the only donor in the case of the Marshall Plan), recipient countries now cope with dozens of official creditors, bilateral donors, UN and other public agencies and international NGOs. All of these in turn operate in dozens of countries (more than 100 in the case of Germany, the Netherlands, the U.S., France, Japan and the U.K. - see Chart 4A). In each country, donors also typically operate in many sectors with many projects. Managing their "own" projects increases donor visibility, and doing so in many countries maximizes donor countries' ability to leverage the diplomatic support of small countries for their objectives (and sometimes their candidates for high posts) in the United Nations and other international settings.

In 2000-2002, the United States disbursed about $\$ 100$ million of aid in Tanzania, financing 50 different projects at an average of just \$2 million apiece (Chart 4B). With more than 1300 projects altogether in that period, and an estimated 1000 donor

\footnotetext{
${ }^{18}$ Personal correspondence with Michael Clemens, and based on the assumption that the rate of increase in net enrollment in South Korea (data for which are not available) tracked roughly the apparent rate of increase in gross enrollment in that decade.
} 
meetings a year and 2400 reports to donors every quarter, Tanzania several years ago announced a four-month holiday during which it would not accept donor visits. ${ }^{19}$

The donors are neither competing nor collaborating. They are in effect colluding something easy to do for suppliers in the absence of a competitive market. ${ }^{20}$ The proliferation of colluding donors (i.e. the tendency of donors to operate in many countries and in many sectors within countries) creates what is now called "fragmentation" at the recipient country level, with the measure of fragmentation rising for each recipient country with the number of donors and the smaller these donors' aid shares. Donors are aware of the resulting high transactions costs recipients face (with many different missions, reporting requirements, procurement rules etc.), and the associated managerial costs for the government (lack of focus and accountability, and competition among sector ministries for external financing independent of overall government priorities).

The donor response has been to work on harmonizing procurement and reporting rules among themselves, which is certainly a step in the right direction. But the cost to recipients of donor fragmentation goes well beyond the reduction in the monetary value of donor transfers of high transactions and managerial costs. With many donors competing with each other for visibility and quick success, donors are treating the limited public sector capacity (and the limited recurrent budget) of recipient countries as a common-pool resource (Brautigam, 2000; Brautigam and Knack, 2004), in effect undermining that resource rather than building it up. Donor proliferation and fragmentation (like impatience) are thus bad for recipient country institutions in the broadest sense of the word. Knack and Rahman (2004) cite "poaching" of local qualified staff by donors as an example, and find that recipients suffering higher donor fragmentation show greater declines in a measure of bureaucratic quality over the period 1982-2001. Their finding is alarming; it suggests that not only do donors not know how to encourage institution building in the low-income countries - they may actually have contributed to undermining those institutions.

Ideally donors would form a common pool of funds, ${ }^{21}$ and then would compete with each other to finance the "best" proposals submitted by recipient countries, regions and other entities. Contributions of donors to multilateral funds such as the World Bank are a step in that direction since they reduce fragmentation at the recipient country level. But they do not create the healthy competition among donors in "buying" good programs and projects that would really put recipients in the driver's seat. Another option would be for donors to create market competition in the provision of aid. In a recent note prepared by the private sector group in the World Bank, the authors make the point that aid agencies can finance aid without providing aid. ${ }^{22}$ Donors could "buy aid services” in a competitive market, generating competition among service delivery

\footnotetext{
${ }^{19}$ Birdsall and Deese, 2004 use this example to introduce an essay on the current U.S. foreign aid program, which is largely unilateral in conception and implementation.

${ }^{20}$ Thus Easterly, 2002b labels the system a cartel of good intentions. "Once a collusive agreement (among donors) is in place, bureaucracies will not cheat on the agreement by supplying a larger quantity of foreign aid services at a lower price,” p. 10. Collusion also allows sharing the blame of failures, which dictates minimal effort at evaluation.

${ }^{21}$ Kanbur and Sandler with Morrison (1999) define and elaborate on the idea of a common pool.

${ }^{22}$ Harford, Hadjimichael and Klein, 2004.
} 
organizations, including in-country civil society and for-profit groups. To the extent some donors now do buy services, their purchases tend to be tied to home contractors even if not officially, and that contracting rarely implies less of a presence of the aid bureaucracy itself in countries.

Regarding contributions to multilateral programs (Chart 4C), it is notable that the US, the UK and Japan, among the largest bilateral donors in absolute spending, give less as a proportion of their own total aid budgets, presumably because their ability to spread greater absolute resources across multilateral and their own bilateral programs secures them influence in both settings.

Donors are well aware of their collective sin of "envy." The OECD Development Assistance Committee is sponsoring pilot programs of donor "harmonization" in eight countries, in which many of the donors operating locally have agreed to pool their financing for general budget support or for major support to large sector programs such as education. The idea is to minimize the burden on recipient governments of multiple and different negotiations, procurement and reporting rules, and disbursement procedures. The HIPC initiative is by accident, if not by initial intention, an excellent example of donor collaboration - in which donors as a group agreed on rules for eligibility and arrangements for implementation. ${ }^{23}$ Donors have also recently sponsored and supported such "global" programs as the Global Fund to Fight AIDS, TB and Malaria, and the Fast Track Program for basic education.

Though the spirit is right behind these various "reform" efforts, the jury is still out on whether they reduce the costs of donor fragmentation for recipients, including the poaching of qualified local staff and the insidious distraction of local officials from managing their own resources and priorities to coping with donors.

\section{A donor (partial) fix}

Bilateral donors could contribute higher shares of their aid to multilateral programs; a gradual increase to 50 percent seems reasonable. More donors could try to concentrate their resources in fewer countries (the Nordics and the UK have announced countries where they will "concentrate" resources). Donors could agree on no more than one or two bilateral "lead" donors in recipient countries with the others providing financing but leaving (say over a 5-year period) management of the dialogue, monitoring, reporting and so on to one or the other lead donor.

Donors could make themselves accountable as a group for their commitments on coordination by giving recipient countries access to some of the commonly financed independent evaluation funds (\#3 below), for periodic assessment and public reporting of each donor's cooperative behavior in their country. Until the evaluation fund is set up, the OECD DAC could make grants to policy groups in poor countries where many donors are active for this purpose, putting a priority on providing a high-level and public forum for reporting and discussion. Just as recipient countries have their

\footnotetext{
${ }^{23}$ Birdsall and Deese, 2004 point out that one benefit of donor collaboration on the HIPC program is that the rules and transfers are somewhat less vulnerable to changes in the political environment within individual donor countries.
} 
behavior scrutinized and discussed in the Boards of the IMF, the World Bank, and other international organizations, so might the behavior of donors be discussed.

Ultimately, however, the idea of solving the problem by greater "coordination" would ideally yield to much more fundamental change. The donors as a group should commission work on how they might, in practical ways, test the waters of a common pool and of "buying" execution of programs instead of direct provision with their own bureaucracies.

\section{\#3. Ignorance (failure to evaluate)}

Official and private agencies that develop and manage development assistance programs hesitate, with some justification, to advertise the limits of their craft. In the donor countries that finance assistance, suspicion that much such assistance is wasted runs high, and exposure of a program's current shortcomings could reduce its future funding. ${ }^{24}$ Even if only a cover for lack of generosity, such suspicions are politically important. It is easier to limit than to expand foreign aid budgets, and in the interests of the latter, those who see and work with the urgent needs of people in poor countries have no obvious incentive to invest in long-term evaluation of what they do.

Moreover, rigorous evaluation of the impact of an intervention is costly. It is likely to seem a distraction for donor officials wanting to be sure programs get implemented, and add to the burdens of the limited number of experienced local staff. For many development assistance programs, there is also the attribution problem. Without baseline information and a controlled experiment, it is difficult to attribute program success or failure to the programs themselves, as opposed to the environment in which they operate and the unpredictable shocks, positive and negative, that influence their effectiveness. Those who develop and manage assistance programs are cursed with their own intimate knowledge of this particular complication, and are understandably wary of subjecting their work to the crude political criticism and limits on new resources for aid programs that transparent evaluation might trigger. ${ }^{25}$

\footnotetext{
${ }^{24}$ It is true that such suspicions seem less powerful in Western Europe than in the United States, Australia, and Canada. Various theories have been suggested to explain the persistent differences across donor countries in the amounts of public foreign aid. One is that where tolerance for income inequality varies across countries, and that where such inequality is higher it is associated with the view that people get what they deserve and if they are poor in faraway places perhaps that is all they deserve. The other is that the form of government in the United States, in which it is possible to have an opposition party controlling the legislative branch, is particularly unfriendly to foreign aid. See Lancaster, forthcoming.

${ }^{25}$ The official agencies do sponsor internal ex post assessment of the interventions they finance. The World Bank has, for example, its OED (Operations Evaluations Department), as do the other multilateral banks and the bilateral aid agencies. The International Monetary Fund recently established an Independent Evaluation Office (IEO), though it took over 50 years before it felt the need to do so, finally responding to the pressure of civil society groups. These offices do a creditable job (the first studies of the IEO are impressive). However their studies are subject to the review and comment not only of staff in the institutions but of the countries whose programs are often the subject of the evaluations. There is a natural process of minimizing the harshness of language, the awareness of which rebounds back to those undertaking these "evaluations.”
} 
That may explain why, in 50 years of postwar foreign aid, systematic evaluation of aid projects has been so rare. ${ }^{26}$ Though the donors have financed billions of dollars worth of projects, few have had built into them the ingredients for a systematic evaluation. The exception is in the field of public health, where the tradition of epidemiological studies using controlled experiments led to such programs as that in Matlab Thana, Bangladesh, the evaluations of bednets to prevent malaria in Tanzania and of the onchocerciasis program in West Africa. But even these are exceptions that prove the apparent rule that it is more convenient and less risky politically to minimize serious evaluation. $^{27}$

The multilateral banks do fund internal ex post assessments of the projects and programs they finance. But they face tremendous attribution problems, and their results and implications are rarely immediately internalized in new decisions, especially if they challenge conventional wisdom or raise awkward questions regarding donors' strategies. $^{28}$ Examples include the HIPC program of debt relief, in which even the second "enhanced" funding was (predictably, given the optimism of the original projections) not adequate to ensure debt sustainability of the recipient countries $^{29}$; the continuing failure of the PRSP (Poverty Reduction Strategy Papers) approach to deliver donor coordination and country ownership ${ }^{30}$; and the structural adjustment programs of the IMF, the World Bank and other donors discussed above.

For all of these, it has generally been independent studies that have created the pressure for enhancements and adjustments.

The lack of emphasis on good evaluation has been immensely costly. In the absence of timely, credible, and independent evaluation, many aid dollars have been misdirected. It took more than a decade, for example, before the IMF "discovered" the repeatedly waived conditionality of its often failed adjustment programs in poor countries - and only then when the multilateral debt of the poorest countries had become so high that the IMF and World Bank were pressed into what appeared to be "defensive lending."31

\section{A donor fix: An independent evaluation fund ${ }^{32}$}

Evaluation is critical to effective use of hoped-for increased donor transfers to help poor countries meet the Millennium Development Goals. The critical ingredients for

\footnotetext{
${ }^{26}$ As Pritchett, 2002 suggests, sometimes it seems to "pay to be ignorant.”

${ }^{27}$ See Levine et al., 2004. This study sponsored by the Health Policy Research Network of the Center for Global Development was based on the 17 (of many more) scaled-up health interventions in the last several decades that had adequate evaluations to be judged successful.

${ }^{28}$ For an example, see Birdsall, Vaishnav and Malik (in process), on the World Bank's decade of lending for poverty reduction in Pakistan.

${ }^{29}$ Birdsall and Williamson, 2002; Birdsall and Vaishnav 2004. For discussion and definitions see Birdsall and Williamson, 2002. For the conclusion that the HIPC II financing was not additional, see Killick, 2004.

${ }^{30}$ OED, 2004. The OED report does not use the term "failure” but the evidence it presents can be so interpreted.

${ }^{31}$ Birdsall, Claessens and Diwan, 2004.

${ }^{32}$ An independent working group sponsored by the Center for Global Development is currently (in 2006) exploring options for increasing and strengthening evaluation of social programs in developing countries, including those financed by donors.
} 
evaluation of development assistance are that it be independent, collectively agreed and financed by a minimum set of the large multilateral creditors and bilateral donors.

Independent evaluation of the effectiveness of the World Bank and other multilaterals has been called for by groups on the left, right and center, including in the last few years a commission of the Overseas Development Council, the Meltzer Commission, and a commission of the Carnegie Endowment. ${ }^{33}$ Donors could finance an independent entity, which would in turn finance evaluation of selected donor-financed programs. Financing could be provided in the form of a small tax on each donor's total annual disbursements. A tax of 0.05 percent on $\$ 60$ billion a year would generate $\$ 30$ million for evaluation - a large amount given spending would complement not substitute for existing internal evaluation programs.

A collective decision, once agreed, would help lock in donor agencies to the good behavior of more and better evaluation, perhaps partly insulating specific programs from the political pressures associated with initial negative evaluation findings, which the agencies justifiably fear. It would allow for much more rapid and less costly adjustment when findings are negative, minimizing the risk of prolonging misguided approaches, which in the end may come back anyway to harm development assistance efforts politically, and which meanwhile have high opportunity costs in foregone wellbeing of the poor. In addition, the visible independence of evaluation results that are good would build the political case for increased financing.

To minimize the risk of creating another bureaucracy, an ex ante "fee" or "tax" on disbursements could be channeled to an entity which would in turn periodically commission third-party independent studies. A minimum set of the large donors-at least four or five would have to participate to insulate the entity from the natural pressures that funding from only one or two donors or agencies would create, and to allow for studies across countries and types of programs and donor modalities.

\section{\#4. Pride (failure to exit)}

The impatience of donors is accompanied, ironically, by an inability and unwillingness to exit from programs and countries where their aid is not helping. By "exit" in this context I do not mean withdrawing from continuing engagement through dialogue, technical advice and even small transfers for training and technical assistance. I mean stopping large financial transfers the benefits of which are reliant on adequate local conditions. (Education abroad could be continued for example.)

Impatience and inability to exit are not inconsistent. Impatience to spend money, even badly, is unfortunately fully consistent with an inability to stop big spending while remaining engaged. Pride (and bureaucratic politics, including the coordination failures among donors discussed above) have generally precluded exit as a way to minimize waste. $^{34}$ In recipient countries in the grey zone, where there is a reasonable but not high expectation of adequate performance, the donors, once committed, tend to let misguided

\footnotetext{
${ }^{33}$ Meltzer, 2000; Birdsall, Sewell and Morrison, 2000; and CEIP and IAD, 2001.

${ }^{34}$ The design of the MCA indirectly reflects the difficulty of exit; it limits the risk of failure by restricting large transfers to recipient countries where there is minimal risk of failure.
} 
optimism (and an enlightened commitment to "do something" for the reform-minded Minister of Agriculture or Health or Finance struggling in a weak or corrupt system) trump good judgment.

A telling example of the reluctance to exit is the repeated rounds of unsuccessful adjustment loans of the IMF, the World Bank, and in most countries a regional development bank to the 20 countries with the most adjustment loans over the 20-year period 1980-1999. Over that period, Côte d'Ivoire, Ghana and Argentina had 26-30 adjustment loans each, and Senegal, Uganda, Mexico, Morocco and Pakistan had 20-25 each (Chart 2). ${ }^{35}$ Perhaps some of those countries would have reformed even less or grown even less without the loans. But Easterly (2002a) finds no evidence of any effects of the programs these loans supported on policy change or on growth. The implication, as he notes, is that "new loans had to be given because earlier loans were not effective." That is also the unpleasant implication of the accumulated debt to the multilateral creditors of low-income countries which failed to grow, yet continued to receive loans in the 1990s which they were unable to service; these countries eventually entered the HIPC program. ${ }^{36}$ Other evidence on failure of the creditors to exit is summarized in the 2002 report of the IMF's Independent Evaluation Office on prolonged lending. Prolonged lending is defined as lending to countries that have been under IMF arrangements for at least 7 years out of any 10. Along the same lines is evidence on repeated waivers of conditionality with cancellation and new loans with new promises reported in Bird et al. (2004) and Joyce (2005).

\section{A donor fix}

Engagement is possible without large flows of assistance. The threat of exit need not imply an unwillingness to finance small programs that focus on institutional support over the long haul and to continue engaging through external training programs and policy dialogue. Donors ought to be prepared more often to exit from support to governments that fail to meet commitments on structural reforms and on projects needed to ensure that growth is pro-poor. At the same time, withdrawal of financial support need not be seen as punishment for bad behavior, but as a reasonable decision to limit the extent to which donor aid is not generating any reasonable return. It makes sense even when governments are willing but unable to use money well, because of internal political constraints or temporarily insufficient absorptive capacity.

Work in the development assistance demands a "can-do" attitude. That leads structurally to enlightened but misguided optimism that success is always just around the corner. A structural shift is needed. Many more programs that involve large transfers could build in exit as the natural default, setting conditions for continuing support, e.g. that the recipient is meeting pre-agreed benchmarks. In some cases that might mean more emphasis on monitoring government performance in such areas as press freedom, protection of property, and micro-reforms to reduce patronage. ${ }^{37}$ In

\footnotetext{
${ }^{35}$ See Easterly, 2002a.

${ }^{36}$ Birdsall, Claessens and Diwan, 2003 show that low-income countries with high indebtedness to the multilateral creditors received new loans even if they scored poorly on the IDA measure of performance.

${ }^{37}$ Using three to five-year contracts, exit as the default could be adopted by the Millennium Challenge Corporation in managing the MCA. Time will tell.
} 
other cases it might simply mean halting disbursements to a particular sector or project - unless and until agreed performance benchmarks are met.

\section{\#5. Sloth (pretending “participation” is sufficient for “ownership”)}

It took too long, but experience and empirical analysis led to the recognition in the 1990s that the conditionality typically included in World Bank and IMF loans (and often implicitly or explicitly followed by other official creditors and donors) was not effective. $^{38}$ Good policy apparently cannot be imposed or even encouraged by bribelike transfers. Good policy, as the discussion of institutions above suggests, seems to be the outcome, at least partially, of the "software" of a society, which in turn is a function of history, geography, customs and other factors that, though malleable in the long run, are difficult to change in the short run. Apparently a country's "ownership” of a reform agenda is the key to implementation of reforms, and not the apparent enforcement of implementation through loan conditions.

But that discovery led to a new kind of simplification (in practice if not in conception), namely that "participation" of citizens through civil society groups is sufficient to secure "ownership." The misguided imposition of policy conditions morphed into the misguided imposition of "participation." In principle the logic of widespread participation in setting a reform agenda makes sense. The theory is that reforms that are not politically feasible will not endure, even if they are implemented (itself unlikely). The expectation of economic actors that reforms will not endure in turn undermines the credibility of promised reforms and thus their potentially positive effects on investment and growth.

But the prevailing approach to participation, as demanded by donors, has been narrow and apolitical. In practical terms it has relied mostly on engagement of civil society groups in discussions of proposed government programs (including the PRSPs). In this form it overlooks the deeper challenge of creating or strengthening durable political mechanisms for resolving disputes and tradeoffs. Members of minority groups and the truly poor are often excluded from apparently open discussions, reflecting the reality that participatory efforts alone are unlikely to alter the prevailing distribution of power and influence. $^{39}$ Democratic governments, particularly in Latin America, argue that emphasis on civil society, especially where large inflows of external funds were concerned, undermine the role of their own legislatures and of local governments in the give and take of political decision-making about economic issues.

It would be wrong to condemn the idea of greater participation in itself. But equally it would be wrong to delude oneself that participation creates or indicates political and social ownership of major reforms.

Moreover in the case of the IMF and the World Bank, the initial and principal purveyors of conditionality, ownership of country reforms at the country level is made more difficult by the lack of real ownership of the institutions' own policies and practices.

\footnotetext{
${ }^{38}$ For example, see Collier et al., 1997 and Gunning, 2000.

${ }^{39}$ Christian Aid, 2002.
} 
Dervis (2005) explains the difficulty of pushing through IMF-supported reforms during Turkey's financial crisis of 2000-2001 because reforms “demanded” by the IMF were seen as representing the interests of foreign banks and businesses. The problem is obvious and analogous to that at the country level: Though developing countries "participate" in the governance of these institutions, they cannot be assumed to "own" the institutions' overall policy approach, given their limited voting shares and limited influence in choosing the leadership of these institutions. Budget decisions and decisions regarding use of net income are different in the Inter-American Development Bank, where borrowers have more votes, more influence, and more ownership (see Chart 3A). ${ }^{40}$

\section{A donor fix}

Donors could experiment with the "foundation" approach, ${ }^{41}$ under which the donor and financier would respond to proposals from governments (and non-government groups) rather than themselves proposing and shaping programs. This passive stance assumes the proposer "owns" the program to be financed; it is one currently used by the Global Fund to Fight Aids, TB and Malaria and is to be used by the U.S. Millennium Challenge Corporation (at least that is the idea). It is probably not, however, a full solution to a complex problem.

What is more fundamental is for donors and particularly the IMF and the multilateral banks to acknowledge that the reforms they advocate are hard to do precisely because they violate the interests of powerful groups, and have no active political constituency. Pro-poor reforms are politically tough to implement - that is the bottom line. Even those that are "owned" by reform-minded ministers or have been discussed with civil society groups will not necessarily get implemented. That implies that donors need to engage, before committing resources, in assessment of the interests of politically powerful stakeholders, the record of existing governments on difficult reforms, and its vulnerability to an ouster if it takes certain steps (see Chart 3B). Promises and "participation" are not an adequate substitute for political ownership, and are no better than traditional conditionality as guarantees of change.

Ultimately developing countries are more likely to be pushed along internally in the direction of pro-poor reforms and complementary market policies only when their own domestic political imperatives support it and when some of the global institutions in which they "participate" are also more fully "owned” by them.

\section{\#6. Greed (unreliable as well as stingy transfers)}

It is odd to accuse donors of stinginess, since by definition they are providing resources voluntarily, and any amount might be viewed as generous. On the other hand, given the claims of "partnership" (for example in the context of the Millennium Development Goals), the donors as a group can be called "stingy", at least relative to their

\footnotetext{
40 See Birdsall, 2003.

${ }^{41}$ Van de Walle, 2005, recommends this approach, while recognizing its dangers and its limits (pp. 9091).
} 
commitments, $^{42}$ Only Denmark, Norway, Sweden and the Netherlands have met the goal of aid as a share of GDP of 0.7 percent to which all committed at Monterrey, Mexico (confirming even earlier commitments) in 2002. ${ }^{43}$

At an average of about 0.3 percent of donor GDP, development assistance spending by the rich countries is extraordinarily low compared to internal transfers. Most of the OECD countries spend at least 20 percent of GDP on transfers for investments in education, health and other quasi-public goods meant to ensure reasonably equal opportunities for their own citizens independent of citizens' income, and for money and in-kind transfers of food, housing and other goods and services as social insurance for families and to alleviate poverty. On the one hand, it is not surprising that internal assistance budgets are much larger than external ones. On the other hand, given increasing global interdependence, rising concern about failing states since the 9/11 attack, and the huge (one-hundred-fold) gap between average income in the richest compared to the poorest countries, a one-hundred fold difference between domestic and overseas transfers suggests a stunning failure to adjust to a changed world.

Donors also tend to portray actual transfers as higher than they are. Of an estimated $\$ 20$ billion reported by bilateral donors as disbursements to the low-income countries in 2002, after subtracting about $\$ 8$ billion for emergency aid and technical cooperation funds (spent mostly on donor contractors), and almost $\$ 4$ billion in repayments of loans and interest, less than 50 percent or $\$ 10$ billion actually went to the low-income countries for direct support. ${ }^{44}$

From the point of view of those managing the economies of low-income countries, as problematic as low absolute amounts is that donors as a group are unreliable. At the country level, donor financing has been volatile, unpredictable, and in the more aiddependent countries procyclical - declining at times when countries need the external infusion most, for example because of a commodity prices shock (and increasing procyclically when a country's own tax revenues are growing.) ${ }^{45}$

Lack of reliability for the recipient country is the result of two factors. First, changes in the foreign aid totals of different donors and in the objectives of the donors as a group affect financing for particular countries and programs. The diversion of funds of large donors for political purposes to one or another country reduces amounts available to other countries and programs. Financing for Iraq (in the case of the U.S.) and for AIDS prevention and treatment are almost certainly reducing aggregate financing now for some countries and for other health and non-health programs. Changes in donor strategy also affect flows. Killick (2004) reports evidence that non-HIPC countries saw a reduction in their share of total donor assistance from 56 to 24 percent between 1998 and 2000, implying a virtually certain reduction in absolute flows for those countries when donors decided to provide debt relief for the most highly indebted countries. There is also evidence that the new aid initiatives of the U.S., for the MCA program and

\footnotetext{
${ }^{42}$ See Center for Global Development and Foreign Policy, 2004, for information on how 21 rich countries ranked in 2002 on the "quantity" (as well as the quality) of aid.

${ }^{43}$ In the 1969 Pearson report, official development assistance of 0.7 percent of GDP was agreed to. See

Moss and Clemens, 2005 for details.

${ }^{44}$ United Nations Millennium Project, 2004, table 13.2.

${ }^{45}$ Bulír and Hamann, 2003.
} 
for AIDS, are associated with reductions in absolute spending on longstanding programs managed by USAID. ${ }^{46}$

Aside from these large shifts, at the country level, aid inflows are uncertain because of the way the aid business operates - with actual disbursements at varying levels year-toyear below commitments, and highly volatile. In the case of Malawi in the 1990s, aid inflows bounced dramatically up and down in the 1990s, between 8 and 20 percent of GDP (Bulír and Hamann, 2001). This would be the equivalent in the U.S. of quintupling the deficit in one year, and then a year later absorbing a huge recession-like effect on jobs and incomes. In many countries in Africa, aid inflows exceed 10 percent of GDP, 50 percent of total revenues, and as much as 60 percent of total new investments. ${ }^{47}$ In these settings, the volatility of aid is systematically greater than the volatility of tax revenues, and clearly exacerbates the problem of economic instability ironically creating challenges for economic management in the countries least able to cope financially because they are unable to borrow internally and because their fiscal and monetary institutions are beleaguered already.

The unreliability and lack of predictability of future donor flows reduces the value of current flows because responsible managers in developing countries cannot make the highest return immediate use of external resources for new investment without assurance of continuing flows to finance the resulting recurrent costs. In many lowincome countries, a decision to scale up teacher training or institute large new programs for treatment of AIDS cannot be made in the absence of predictable and reliable future donor financing of the resultant higher stream of salary and other costs over many years. Similarly the decision to build new rural roads will not be rational if the medium-term financing for maintenance, agricultural extension and other services needed to allow farmers to exploit the resulting larger market cannot be assured.

The cost of unreliability is not only in the volatility of existing flows and the effects on existing programs. The higher cost may be the complete absence of otherwise highly effective programs. An example is financing of research on vaccines against malaria and other tropical diseases. In the absence of an apparently profitable market since the victims of these diseases are mostly poor and reside in poor countries, pharmaceutical firms have no incentive to produce them. Even where pharmaceutical products exist, if they are used primarily in developing countries, they will be more expensive and less reliably available because of the absence of guaranteed donor financing for long-term purchase contracts. $^{48}$

\section{Donor fixes?}

On the amount of aid, there is some hope that the Monterrey promises will yield gradual increases - though still below what a truly global system demands not only to respond to the moral and humanitarian challenge of the poor but in the enlightened interests of the rich in an increasingly interdependent system. Atkinson (2003) discusses many other ideas that have been on the table in one form or another for some years, for example, a Tobin tax on currency transactions and a global lottery. Gordon Brown,

\footnotetext{
${ }^{46}$ Bhavnani, Birdsall and Shapiro, 2004.

${ }^{47}$ O’Connell and Soludo, 1998.

${ }^{48}$ Birdsall and Moss, 2004.
} 
Chancellor of the Exchequer of the UK, has proposed creating a facility that could borrow on private markets now to ramp up available financing. A tiny tax on carbon emissions would raise billions for foreign assistance, and have the additional benefit of possibly reducing those emissions. Birdsall and Williamson (2002) propose sale or revaluation of IMF gold to provide insurance-like coverage to HIPC countries subject to external shocks. Soros (2002) proposes creation of new special drawing rights (SDRs) at the IMF with the resulting finances targeted to the poor countries.

Addressing the problem of unpredictable and volatile flows requires a bigger step away from business as usual. The proposal of Gordon Brown of the UK for an International Financing Facility, to borrow from private markets and fund the resulting debt using future donor allocations, is meant to double the annual amount of financing immediately. Its greater benefit may be that it creates a mechanism that could also make future flows more reliable and predictable, since donors could borrow in the near term and commit to maintain flows to particular countries or programs independent of subsequent uncertain legislative approvals. ${ }^{49}$ Essentially the donor community needs to develop new trust or endowment-type instruments for longer-term, more "patient" and more predictable funding of development assistance. The real fix to the lack of predictability almost certainly has to come as the result of this sort of larger breakthrough in the overall aid architecture.

\section{\#7. Foolishness (underfunding of global and regional public goods ${ }^{50}$ )}

Donors direct almost all of their resources to individual recipient countries, as opposed to regional groupings and global public goods. Financing for global public goods has grown in the last decade, primarily in response to the pressures of environmental groups in the rich countries. In the case of global public goods, rich countries have an evident self-interest, though of course much of the spending benefits developing countries as well. But global public goods that would primarily benefit developing countries are almost surely underfunded. That includes tropical agricultural research given its extraordinarily high past returns relative to most country programs and projects, and research on malaria and AIDS vaccines. ${ }^{51,52}$

Regional public goods have received even less attention. Of the approximately $\$ 60$ billion in development aid disbursed in 2002, a rough guess would be that at most $\$ 1$ to $\$ 2$ billion was spent on multi-country programs and projects in the developing world, such as harmonization of stock markets in Africa, or development of a shared electricity

\footnotetext{
${ }^{49}$ In late November 2004, the UK announced it will support a scheme of guaranteed purchases of malaria and AIDS vaccines. For discussion of this kind of advanced market or pull mechanism, see Levine, Kremer, and Albright, 2005 and Kremer and Glennerster 2004.

${ }^{50}$ This section is taken mostly from Birdsall, 2004, which includes sources and citations for the points made here.

51 The case for more donor spending on global public goods is especially compelling given the short-term problems of absorption capacity which limits effective, institution-friendly donor spending in many poor countries.

${ }^{52}$ On agriculture see Evenson, 1987. On vaccines see Levine, Kremer, and Albright, 2005 and Levine et al., 2004.
} 
grid in Central America, or multi-country roads and watersheds in Asia (Chart 5). ${ }^{53}$ The rest was channeled through agreements with national governments of individual countries in what might be called conventional country-focused assistance. The World Bank and the regional banks as well as the UN agencies operate mostly at the country recipient level - in the case of the banks in part because their principal instrument is the country loan.

There has been virtually no analysis of the potential returns to greater investments in regional and transnational or multi-country public and quasi-public goods. I argue elsewhere, however, that as is the case with all public goods (the benefits of which cannot be confined to those who finance them), regional public and quasi-public goods are underfunded - by countries who would potentially benefit from them, and by donors concerned with increasing growth and poverty reduction in those countries and their neighbors. ${ }^{54}$ Lost opportunities for high-return investments are most obvious for subSaharan Africa, where the "internal” market (all of sub-Saharan Africa including South Africa) is only about the size of the economy of Chicago. That is sufficient to support specialization and scale investments were it fully integrated into a single market. But of course it is not. Poor roads and other infrastructure, bureaucratic delays and corruption in customs, and absence of network externalities in sea and air transport all contribute to high border costs. And the large number of countries ensures that there are many of these costly borders.

If the returns to regional investments are potentially high, why are those investments not made? Regional investments are likely to be underfunded (compared to some unknown optimum which we do not know, given the difficulty of estimating benefits of investments in public goods in general) by developing country governments for two reasons: recipient countries' own domestic political systems will be more responsive to social demands for country-specific public goods such as universal primary education, roads and public health; and there are substantial coordination problems associated with cooperating with other governments. Donors, in turn, face two problems. To the extent donors respond to the explicit immediate interests of recipient governments, they will see a tradeoff between encouraging investment in regional public goods and institutions and recipient "ownership" - though this may just underline the risks of too narrow a concept of country "ownership." The donor focus on ownership and greater harmonization does not address the institutional problem that recipient countries face in coordinating among themselves.

Second, the funding of regional programs is complicated for donors. Some of the fault lies with developing countries who have limited political incentives to cooperate. For the multilateral banks, there is the additional problem of lack of grant funds. Loan commitments to groups of recipient countries are difficult to make since they would require a clear allocation of repayment and other legal obligations to each borrower, which is difficult to negotiate. (Thus for the banks, the country loan as an instrument has dictated the logic of organizing operational staff and budgets into country teams

\footnotetext{
${ }^{53}$ Some private foundations such as Gates and Rockefeller put large portions of their total grant-making into global programs which sometimes operate at the "regional" level, but even in these cases, the focus is global.

${ }^{54}$ Birdsall, 2004.
} 
with country-based allocations for lending.) Bilateral donors have grant resources, but need a single interlocutor who can be held accountable - and their aid recipients would rather put grants they can get into their own country programs. Bilateral donors also face the risk of a "weak link" country in the chain of effectiveness. For example a major program with SADC (the Southern African Development Community) could be hurt if donors felt the need to cut off all aid to Zimbabwe.

In short, global public goods that would primarily benefit developing countries are almost surely underfunded by donors. The case is even stronger for regional public goods given the absence of any self-interest on the part of donors and the additional costs and risks compared with country-focused assistance.

\section{A donor fix?}

The donor community should put the challenge of greater support for global and regional programs on the table for discussion. ${ }^{55}$ As a start, the Development Assistance Committee of the OECD could establish common reporting requirements for the bilateral donors and multilateral creditors on their support for global and regional programs and projects. This would establish the minimum of information needed for even cursory assessment of the relative cost-effectiveness of global and regional institutions and programs.

Some donors could take responsibility for special emphasis on the strengthening of regional institutions; this seems particularly important for sub-Saharan Africa, where France and the UK might take a greater lead. The increasing presence of the Economic Commission for Africa and the formation of Nepad are good signs of progress with African ownership of its development challenges as a region; donors ought to be unusually receptive to these African initiatives. Multi-country physical infrastructure projects should be a priority, despite the fact they may take longer to design and organize and may not seem to have the immediate ownership or easily measurable effects in relation to the Millennium Development Goals. The incipient demand is huge, yet not reflected in the rhetoric of donors nor much considered in PRSPs, which tend to focus heavily on increased social spending. In the trade area, where so much could be done to reduce the high costs of borders, there seems little question that African policymakers would benefit from clear incentives to consolidate what are now at least a dozen trade agreements within the region, all but three of which have no more than two or three members.

Finally, the constraint that the multilateral development banks face in actively supporting global and regional programs needs attention. What financing they have done has come from Trust Funds and from their highly limited grant funding. The donors could encourage more use of net income to finance these initiatives, by giving the middle-income countries whose borrowing costs would be affected more influence in setting priorities for use of net income. This would make particular sense in the regional development banks. South Africa might push for such a pilot program of this

\footnotetext{
${ }^{55}$ A working group at the Center for Global Development has proposed that the shareholders of the World Bank and the Inter-American Development Bank consider a much stronger mandate with adequate financing to substantially expand their financial, strategic, and technical support for respectively, global and regional public goods. See Birdsall and Kapur, 2005 and CLAAF and CGD, forthcoming.
} 
type at the African Development Bank (except that it borrows so little from the hard window that its membership does not generate net income). Bilateral donors could also develop facilities that would finance guarantees for regional groups that were borrowing from the multilateral banks or the private market, or could subsidize the borrowing costs to individual countries participating in regional borrowings.

For donors, the fundamental challenge is not actually in the details of what or how to address support for regional and global public goods in the developing world. It is how to address their own lack of incentives to work actively in these areas.

\section{A Summary of Donor Fixes}

\section{\#1. Impatience (with institution building)}

This is the most central and fundamental challenge. A first step would be for the donor community to acknowledge its overall past failure, and undertake a collective assessment of how to address that failure, in close and constant consultation with wise people from the developing countries. If it cannot be done collectively (for example at the Development Assistance Committee of the OECD), leadership will have to taken by a single large bilateral donor such as the U.S. or the UK. ${ }^{56}$

\section{\#2. Envy (collusion and coordination failures)}

Minor fixes could include agreement of the bilateral donor governments to increase the portion of their total assistance spending that goes to multilateral institutions and programs; agreement to the concept of lead donors in highly aid-dependent countries, and the financing through DAC of grants to developing country policy groups to report on in-country performance of the individual donors. Like impatience, however, this challenge is fundamental, and may not yield to minor fixes. The major fix would be establishment of a true common pool of donor funds.

\section{\#3. Ignorance (failure to evaluate)}

A minimum number of major donors could make a collective agreement to self-finance a fully independent evaluation entity, which would in turn contract third-party evaluations of selected donor-financed projects and programs, and of donor behaviors and modalities.

\section{\#4. Pride (failure to exit)}

New longer-term, more accordion-like instruments are needed that make exit (defined as stopping the flow of large transfers not as abandoning engagement through dialogue and advisory services) the default. Exit should be established as the norm, not as punishment or judgment, but as a natural response to signs that investments being financed will not yield adequate returns.

\footnotetext{
56 The World Bank could be asked to do technical work; much is already set out in World Bank, 2004. It is a matter of turning analysis into ideas for new instruments, procedures, and practices.
} 
\#5. Sloth (pretending participation is sufficient for ownership)

Donors need to end their apolitical approach to ownership, and engage instead in assessment of the interests of politically powerful stakeholders, the record of existing governments on difficult reforms, and governments' vulnerability to an ouster if it takes certain steps. This is particularly critical in the case of pro-poor reforms, since they usually undermine powerful interests and have weak domestic constituencies. Ultimately, it may be that only when developing country recipients have more voice (and votes) in the major institutions will they assume real "ownership" of pro-poor economic and political reforms donors wish to support.

\#6. Greed (unreliable as well as stingy transfers)

Instruments that build in less volatile and more predictable financing are needed, as well as larger aid budgets. New ideas are on the table, in part impelled by the commitments rich countries made in the context of the MDGs. But they are more visible with respect to the amount of aid than with respect to its predictability; the latter requires more radical rethinking of current instruments and practices.

\section{\#7. Foolishness (underfunding of global and regional public goods)}

Financing of global and regional public goods needs a big push. The case for regional programs in Africa is especially obvious; a donor champion - probably the British or the French who could push for a revamping of the singular country focus that now prevails is needed. Grant funds at the multilateral banks would create internal incentives for supporting global and regional investments; they could be supported in part by transfers of net income from the hard windows of the banks, were the middleincome countries whose borrowing costs were affected given more control over the use of those resources.

Perhaps it is worth concluding with a rephrasing of some of my introductory language. My purpose has not been to condemn the donor "sins" (since in this area shame and blame are not likely to work anyway) but to generate a broader, more ambitious conversation among all interested parties. Some "sins", such as the tying of aid to a donor's own services and goods, are already on the reform agenda of the official community and I have not discussed them here. Instead I have tried to focus on shortcomings of the "business of aid" on which new research has or could shed light, and which have not yet been adequately or explicitly incorporated into the donor community's reform agenda. These shortcomings of the business matter tremendously, especially in the context that the focus on achieving the MDGs by 2015 has brought. That is because research shows that they reduce considerably the effective value of the aid that is transferred, and in the most aid-dependent countries may even mean that the "business of aid" actually undermines those countries' long-term development prospects. 


\section{References}

Acharya, Arnab, Ana Fuzzo de Lima and Mick Moore. 2003. “The Proliferators: Transactions Costs and the Value of Aid.” IDS Working Paper. Institute of Development Studies. Sussex, UK.

Acemoglu, Daron, Simon Johnson, and James Robinson. 2004. "Institutions as the Fundamental Cause of Long-Run Growth.” NBER Working Paper 10481. National Bureau of Economic Research. Cambridge, MA.

Atkinson, Tony. 2003. “Innovative Sources for Development Finance - Global Public Economics.” Annual Bank Conference on Development Economics in Europe, May 15-16 (Plenary Session).

Bhavnani, Rikhil, Birdsall, Nancy and Isaac Shapiro. 2004. "Whither Development Assistance? An Analysis of the President's 2005 Budget Request.” Center for Global Development and Center on Budget and Policy Priorities. Washington, DC.

Bird, Graham, Mumtaz Hussain and Joseph P. Joyce. 2004. “Many Happy Returns? Recidivism and the IMF.” Journal of International Money and Finance 23(2): 231-252.

Birdsall, Nancy. 2005. "Why It Matters Who Runs the IMF and the World Bank." In Gustav Ranis, James Raymond Vreeland, and Stephen Kosack (eds.), Globalization and the Nation State: The Impact of the IMF and the World Bank.. London: Routledge.

Birdsall, Nancy and Devesh Kapur, co-chairs. 2005. The Hardest Job in the World. Five Crucial Tasks for the New President of the World Bank. Report prepared by the Center for Global Development World Bank Working Group. http://www.cgdev.org/content/publications/detail/2868/

Birdsall, Nancy. 2004. "Underfunded Regionalism in the Developing World.” CGD Working Paper 49. Center for Global Development: Washington, DC. Forthcoming in Inge Kaul and Pedro Conceição (Eds.) The New Public Finance: Responding to Global Challenges. Oxford University Press: New York.

Birdsall, Nancy and Brian Deese. 2004. "Hard Currency Unilateralism Doesn’t Work for Foreign Aid Either.” Washington Monthly (March).

Birdsall, Nancy and Todd Moss. 2004. "How Wall Street Can Aid the Poor of the World." Financial Times, 30 April.

Birdsall, Nancy and Arvind Subramanian. 2004. "Saving Iraq from Its Oil.” Foreign Affairs Vol. 83(4): 77-89 (July/August).

Birdsall, Nancy and Milan Vaishnav. 2004. "Getting to Home Plate: Why Smarter Debt Relief Matters for the Millennium Development Goals.” Prepared for the Helsinki Process on Globalisation and Democracy, March 26-28. <http://www.cgdev.org/docs/Debt\%20Relief\%20and\%20the\%20MDGs.pdf>

Birdsall, Nancy, Stijn Claessens and Ishac Diwan. 2004. "Policy Selectivity Foregone: Debt and Donor Behavior in Africa.” World Bank Economic Review 17(3): 409-435.

Birdsall, Nancy, Milan Vaishnav and Adeel Malik (in process) "Poverty and the Social Sectors: the World Bank in Pakistan.” Report for the Operations Evaluations Department of the World Bank. 
Birdsall, Nancy and Michael Clemens. 2003. "From Promise to Performance: How Rich Countries Can Help Poor Countries Help Themselves.” CGD Brief Vol. 2(1). Center for Global Development. Washington, DC.

Birdsall, Nancy and John Williamson. 2002. Delivering on Debt Relief. From IMF Gold to a New Aid Architecture. Center for Global Development. Washington, DC.

Brautigam, Deborah. 2000. Aid Dependence and Governance. Almqvist \& Wiksell International: Stockholm, Sweden.

Brautigam, Deborah A. and Stephen Knack. 2004. "Aid Dependence, Institutions and Governance in Sub-Saharan Africa.” Economic Development and Cultural Change 52(2): 255-285.

Bulír, Aleš and Timothy D. Lane. 2004. “Aid and Fiscal Management.” In Sanjeev Gupta, Benedict Clements, and Gabriela Inchauste (Eds.) Helping Countries Develop. The Role of Fiscal Policy. International Monetary Fund: Washington, DC.

Bulír, Aleš and A. Javier Hamann. 2003. “Aid Volatility: An Empirical Assessment.” IMF Staff Papers 50(1): 64-89.

Bulír, Aleš and A. Javier Hamann. 2001. "How Volatile and Predictable Are Aid Flows, and What Are The Policy Implications?” IMF Working Paper No. 01/167. International Monetary Fund. Washington, DC.

Burnside, Craig and David Dollar. 2000. “Aid, Policies and Growth.” American Economic Review 90(4): 847-868.

Burnside, Craig and David Dollar. 2004. “Aid, Policies and Growth: Revisiting the Evidence”, World Bank Policy Research Paper No. O-2834. World Bank. Washington, DC.

CEIP and IAD. 2001. “The Role of the Multilateral Development Banks in Emerging Markets.” Carnegie Endowment for International Peace and the Inter-American Dialogue. Washington, DC.

Center for Global Development and Foreign Policy. 2004. "Ranking the Rich 2004.” Foreign Policy (May/June).

Center for Global Development and Foreign Policy. 2003. "Ranking the Rich.” Foreign Policy (May/June).

CGD. 2004. On the Brink. Weak States and U.S. National Security. Center for Global Development. Washington, DC.

Christian Aid. 2002. “Quality Participation in Poverty Reduction Strategies. Experiences from Malawi, Bolivia and Rwanda.” <http://www.christianaid.org.uk/iindepth/0208qual/quality.htm>

CLAAF and CGD. Forthcoming. Priorities and Challenges for the New Era of the Inter-American Development Bank. Draft. Comité Latinoamericano de Asuntos Financieros and Center for Global Development.

Clemens, Michael, Steve Radelet, and Rikhil Bhavnani. 2004. "Counting Chickens When They Hatch: The Short-Term Effect of Aid on Growth.” CGD Working Paper 44. Center for Global Development. Washington, DC.

Clemens, Michael. 2004. 'The Long Walk to School: International Education Goals in Historical Perspective.” CGD Working Paper 39. Center for Global Development. Washington, DC. 
Clemens, Michael, Charles J. Kenny and Todd Moss. 2004. "The Trouble with the MGDs: Confronting Expectations of Aid and Development Success.” CGD Working Paper 40. Center for Global Development Washington, DC.

Cline, William. 2004. Trade Policy and Global Poverty. Center for Global Development. Washington, DC.

Cline, William. 2003. "HIPC Debt Sustainability and Post-Relief Lending Policy.” Issue Paper on Debt Sustainability (August). HIPC Unit, World Bank. Washington, DC.

Collier, Paul and Anke Hoeffler. 2002. "Aid, Policy, and Growth in Post-Conflict Societies." World Bank Development Research Group. Washington, DC.

Collier, Paul and David Dollar. 2002. "Aid Allocation and Poverty Reduction.” European Economic Review 46(8): 1475-1500.

Collier, Paul and David Dollar. 2000. "Can the World Cut Poverty in Half? How Policy Reform and Effective Aid Can Meet the International Development Goals.” World Bank Policy Research Working Paper 2403. World Bank. Washington, DC.

Collier, Paul, Patrick Guillaumont, Sylviane Guillaumont, and Jan Willem Gunning. 1997. "Redesigning Conditionality.” World Development 25(9): 1399-1407.

DAC. 2001. "Poor Performers: Basic Approaches for Supporting Development in Difficult Partnerships.” Note by the Secretariat, DCD/DAC(2001)26/REV1. Organisation for Economic Co-operation Development: Paris, France.

Dervis, Kemal. 2005. A Better Globalization. Perspectives on Legitimacy Reform and Global Governance. Center for Global Development. Washington, DC.

Easterly, William, Ross Levine and David Roodman. 2003. "New Data. New Doubts: A Comment on Burnside and Dollar’s ‘Aid, Policies, and Growth (2000)'.’NBER Working Paper 9846. National Bureau of Economic Research. Cambridge, MA.

Easterly, William. 2002a. "What Did Structural Adjustment Adjust? The Association of Policies and Growth with Repeated IMF and World Bank Adjustment Loans." CGD Working Paper 11. Center for Global Development. Washington, DC.

Easterly, William. 2002b. "The Cartel of Good Intentions: Bureaucracy versus Markets in Foreign Aid.” CGD Working Paper 4. Center for Global Development. Washington, DC.

Easterly, William and David Dollar. 1999. "The Search for the Key: Aid, Investment, and Policies in Africa.” Journal of African Economies 8(4): 546-577.

Evenson, Robert E. 1987. "The International Agricultural Research Centers: Their Impact on Spending for National Agricultural Research and Extension.” CGIAR Study Paper 22. Consultative Group on International Agricultural Research.

Gunning, Jan Willem. 2000. "The Reform of Aid: Conditionality, Selectivity and Ownership.” Paper presented at Aid and Development Conference, Stockholm, 21-22 January. $<$ http://www.sida.se/Sida/articles/3600-3699/3676/papgun.pdf>

Gupta, Sanjeev, Benedict Clements, Alexander Pivovarsky, and Erwin R. Tiongson. 2004. “Foreign Aid and Revenue Response: Does the Composition of Aid Matter?” In Sanjeev Gupta, Benedict Clements, and Gabriela Inchauste (Eds.) Helping Countries Develop. The Role of Fiscal Policy. International Monetary Fund: Washington, DC. 
Hansen, Henrik and Finn Tarp. 2001. "Aid and Growth Regressions.” Journal of Development Economics 64(2): 547-570.

Harford, Tim, Bita Hadjimichael, and Michael Klein. 2004. “Aid Agency Competition.” World Bank Private Sector Development Presidency, Note 277. Washington, DC.

Hausmann, Ricardo and Rodrik, Dani. 2002. "Economic Development as Self-Discovery.” NBER Working Paper 8952. National Bureau of Economic Research. Cambridge, MA.

Hibbs, Douglas A., Jr. and Ola Olsson. 2004. "Geography, Biogeography and Why Some Countries are Rich and Others Poor." Proceedings of the National Academy of Sciences of the United States 2004, Vol. 101: 3715-3720.

IDA. 2003. "IDA's Commitments, Disbursements and Funding in FY03." International Development Association Board Report 27081. World Bank. Washington, DC.

IDA. 2004. "Allocating IDA Funds Based on Performance. Fourth Annual Report on IDA's Country Assessment and Allocation Process." International Development Association. Washington, DC.

IEO. 2002. "Evaluation of Prolonged Use of IMF Resources." Internal Evaluations Office of the International Monetary Fund. Evaluation Report. Washington, DC.

IMF and IDA. 2004. "Debt Sustainability in Low-Income Countries: Further Considerations on an Operational Framework and Policy Implications.”

$<$ http://siteresources.worldbank.org/INTDEBTDEPT/PolicyPapers/20279458/DSfullpapers ept.pdf $>$

Inter-American Development Bank. 2003. “Annual Report.” Washington, DC.

Joyce, Joseph P. 2005 (forthcoming) "Time Present and Time Past: A Duration Analysis of IMF Program Spells.” Review of International Economics 13(2).

Joyce, Joseph P. 2003. "Promises Made, Promises Broken: A Model of IMF Program Implementation.” Wellesley College Department of Economics Working Paper \#2003-04.

Kanbur, Ravi and Todd Sandler with Kevin Morrison. 1999. "The Future of Development Assistance: Common Pools and International Public Goods.” Overseas Development Council Policy Essay 25. Washington, DC.

Kaufmann, Daniel, Aart Kraay, and Pablo Zoido-Lobaton. 2002. "Governance Matters II: Updated Indicators for 2000/01.” World Bank Policy Research Working Paper 2772. World Bank. Washington, DC.

Killick, Tony. 2004. "Politics, Evidence and the New Aid Agenda." Development Policy Review 22(1): 5-29. Overseas Development Institute. London.

Knack, Stephen. "Aid Dependence and the Quality of Governance: A Cross-Country Empirical Analysis.” Southern Economic Journal 68(2): 310-29.

Knack, Stephen, and Aminur Rahman. 2004. "Donor Fragmentation and Bureaucratic Quality in Aid Recipients.” World Bank Policy Research Working Paper 3186. World Bank. Washington, DC.

Kremer, Michael and Rachel Glennerster. 2004. Strong Medicine: Creating Incentives for Pharmaceutical Research on Neglected Diseases. Princeton University Press: Princeton, NJ. 
Lancaster, Carol. Forthcoming. Fifty Years of Foreign Aid.

Levine, Ruth and the What Works Working Group with Molly Kinder. 2004. Millions Saved. Proven Successes in Global Health. Center for Global Development. Washington, DC.

Levine, Ruth, Michael Kremer, and Alice Albright. 2005. Making Markets for Vaccines: Ideas to Action. Center for Global Development. Washington, DC.

Meltzer, Allan H. 2000. "Report of the International Financial Institution Advisory Commission.” $<$ http://www.house.gov/jec/imf/meltzer.pdf $>$

Moss, Todd, Gunilla Pettersson, and Nicolas van de Walle. 2005. "An Aid-Institutions Paradox? A Review Essay on Aid Dependency and State Building in Sub-Saharan Africa.” Mario Einaudi Center for International Studies Working Paper No. 11-05. Ithaca, NY.

Moss, Todd and Michael Clemens. 2005. "Ghost of 0.7\%: Origins and Relevance of the International Aid Target.” CGD Working Paper 68. Center for Global Development. Washington, DC.

North, Douglass C. 1990. Institutions, Institutional Change, and Economic Performance. Cambridge University Press: Cambridge, UK.

O’Connell, Stephen A. and Charles C. Soludo. 1998. "Aid Intensity in Africa.” CSAE Working Paper 88. Centre for the Study of African Economies. Oxford, UK.

ODC. 2000. "The Right Role for the IMF in Development.” Overseas Development Council Task Force Report (May). Washington, DC.

Pearson, Lester B. 1969 Partners in Development. Report of the Commission on International Development. New York: Praeger.

Picciotto, Robert. 2004. “Aid and conflict: The Policy Coherence Challenge.” Paper presented at the Security and Development Workshop, New Delhi, January 25-26, organized by the Global Policy Project. <http://www.wider.unu.edu/conference/conference-20041/conference\%202004-1-papers/Picciotto-2505.pdf>

Pritchett, Lant. 2002. "It Pays to Be Ignorant: A Simple Political Economy of Rigorous Program Evaluation.” Journal of Policy Reform Vol. 5(4): 251-269.

Radelet, Steve, Sarah Lucas, and Rikhil Bhavnani. 2004. "2004 MCA Threshold Program: A Comment on Country Selection.” Center for Global Development. Washington, DC.

Radelet, Steve. 2004. Challenging Foreign Aid. A Policymaker's Guide to the Millennium Challenge Account. Center for Global Development. Washington, DC.

Radelet, Steve. 2004. “Aid Effectiveness and the Millennium Development Goals.” CGD Working Paper 30. Center for Global Development. Washington, DC.

Rajan, Raghuram G. and Arvind Subramanian. 2005. "Aid and Growth: What Does the CrossCountry Evidence Really Show?" NBER Working Paper W11513. National Bureau of Economic Research. Cambridge, MA.

Reisen, Helmut, Marcelo Soto, and Thomas Weithöner. 2004. "Financing Global and Regional Public Goods through ODA: Analysis and Evidence from the OECD Creditor Reporting System.” OECD Working Paper 232. Organisation for Economic Co-operation and Development. Paris, France. 
Rigobon, Roberto and Dani Rodrik. 2004. "Rule of Law, Openness, and Income: Estimating the Interrelationships.” NBER Working Paper W10750. National Bureau of Economic Research. Cambridge, MA.

Rodrik, Dani. 2000. “Institutions for High-Quality Growth: What They Are and How to Acquire Them.” NBER Working Paper 7540. National Bureau of Economic Research. Cambridge, MA.

Rodrik, Dani. 2003. “Growth Strategies.” CEPR Discussion Paper 4100. Centre for Economic Policy Research. London, UK.

Rodrik, Dani. 2004. “Getting Institutions Right.” <http://ksghome.harvard.edu/ drodrik/ifoinstitutions\%20article\%20_April\%202004_.pdf >

Roodman, David. 2003. "The Anarchy of Numbers: Aid, Development, and Cross-Country Empirics.” CGD Working Paper 32. Center for Global Development Washington, DC.

Soros, George. 2002. George Soros on Globalization. Public Affairs. Oxford, UK.

Stewart, Frances. Forthcoming. "Development and security.” CRISE Working Paper 3. Centre for Research on Inequality, Human Security and Ethnicity. Oxford, UK.

United Nations Millennium Project. 2004. “Global Plan to Reach the Millennium Development Goals.” November 12 draft.

Van de Walle, Nicolas. 2005. Stagnation, Power and Politics in Aid-Dependent Countries. Center for Global Development: Washington DC.

Weinstein, Jeremy. 2004. "Which Path to Peace? Autonomous Recovery and International Intervention in Comparative Perspective.” Mimeo, Stanford University.

World Bank. 2004. World Development Report 2004. Making Services Work for the Poor. Washington, DC.

World Bank. 2003. Annual Report. Washington, DC.

World Bank. 2002. "World Bank Group Work in Low-Income Countries Under Stress. A Task Force Report.” Washington, DC. 


\section{Chart 1A.}

Qualifying (or not) for the MCA

\begin{tabular}{ccc}
\hline $\begin{array}{c}\text { Countries eliminated from the MCA } \\
\text { by the corruption criteria }\end{array}$ & $\begin{array}{c}\text { Countries eligible to apply for MCA } \\
\text { assistance for FY2004 }\end{array}$ & $\begin{array}{c}\text { CPIA ranking by quintile } \\
2002\end{array}$ \\
\hline Albania & - & 2 \\
Bangladesh & - & 2 \\
Malawi & - & 3 \\
Moldova & Mozambique & 3 \\
Mozambique & Countries eligible to apply for MCA & 3 \\
\hline Missed MCA by one indicator & assistance for FY2004 & \\
(out of 16) & Benin & 2 \\
\hline Benin & - & 2 \\
Burkina Faso & Georgia & 4 \\
Georgia & - & 1 \\
India & Mali & 2 \\
Mali & - & 1 \\
Mauritania & - & 5 \\
Togo & - & 5 \\
\hline & Additional countries eligible to apply & \\
\hline & for MCA assistance for FY2004 & 4 \\
\hline
\end{tabular}

Note: The countries listed under each gap are a selection from a larger set of countries.

Sources: Radelet (2003) and International Development Association (2004).

\section{Chart 1B.}

\section{Inconsistency in country rankings}

\begin{tabular}{|c|c|c|}
\hline $\begin{array}{c}\text { Countries in top two quintiles of the CPIA } \\
\text { and } \\
\text { with a Security Gap }\end{array}$ & $\begin{array}{c}\text { Countries in top two quintiles of the CPIA } \\
\text { and } \\
\text { with a Legitimacy Gap }\end{array}$ & $\begin{array}{c}\text { Countries in top two quintiles of the CPIA } \\
\text { and } \\
\text { with a Capacity Gap }\end{array}$ \\
\hline Senegal & Vietnam & Bhutan \\
\hline Sri Lanka & Pakistan & India \\
\hline Uganda & Rwanda & Mauritania \\
\hline Indonesia & & Senegal \\
\hline Nepal & & Burkina Faso \\
\hline \multirow[t]{3}{*}{ Rwanda } & & Indonesia \\
\hline & & Mali \\
\hline & & Pakistan \\
\hline
\end{tabular}

Note: The security gap measures conflict in low-income countries 1998-2003, and the level of conflict is used as a proxy for how effectively governments can preserve internal security.

Sources: International Development Association (2004); and "On the Brink. Weak States and U.S. National Security." A report of the Commission on Weak States and U.S. National Security. Sponsored by the Center for Global Development 2004. 


\section{Chart 1C.}

The Transition in net primary enrollment: all countries 1960-2000

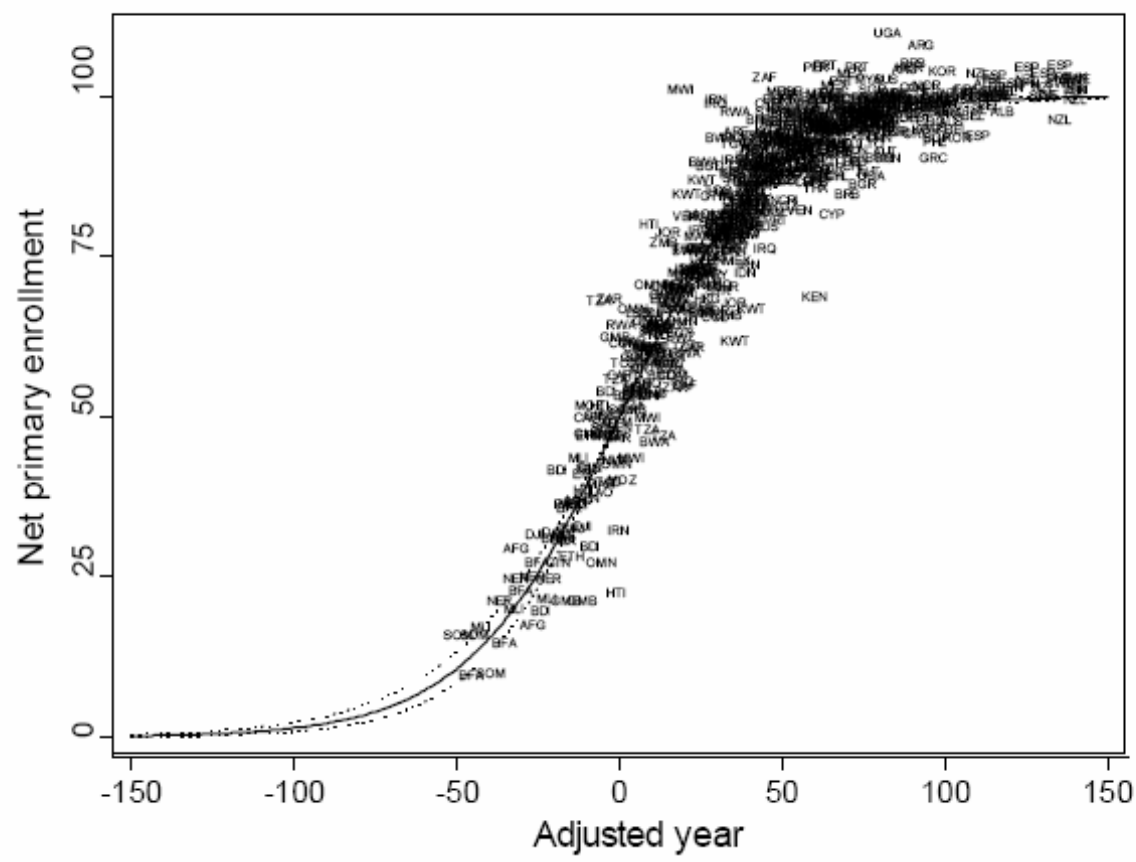

Notes: "Adjusted years" are the elapsed time since 50\% enrollment. Datapoints show country-years, spaced quinquennially.

Source: Clemens (2004).

Chart 1D.

Burkina Faso - Unlikely to meet the school enrollment MDGs but performing strongly by historical standards

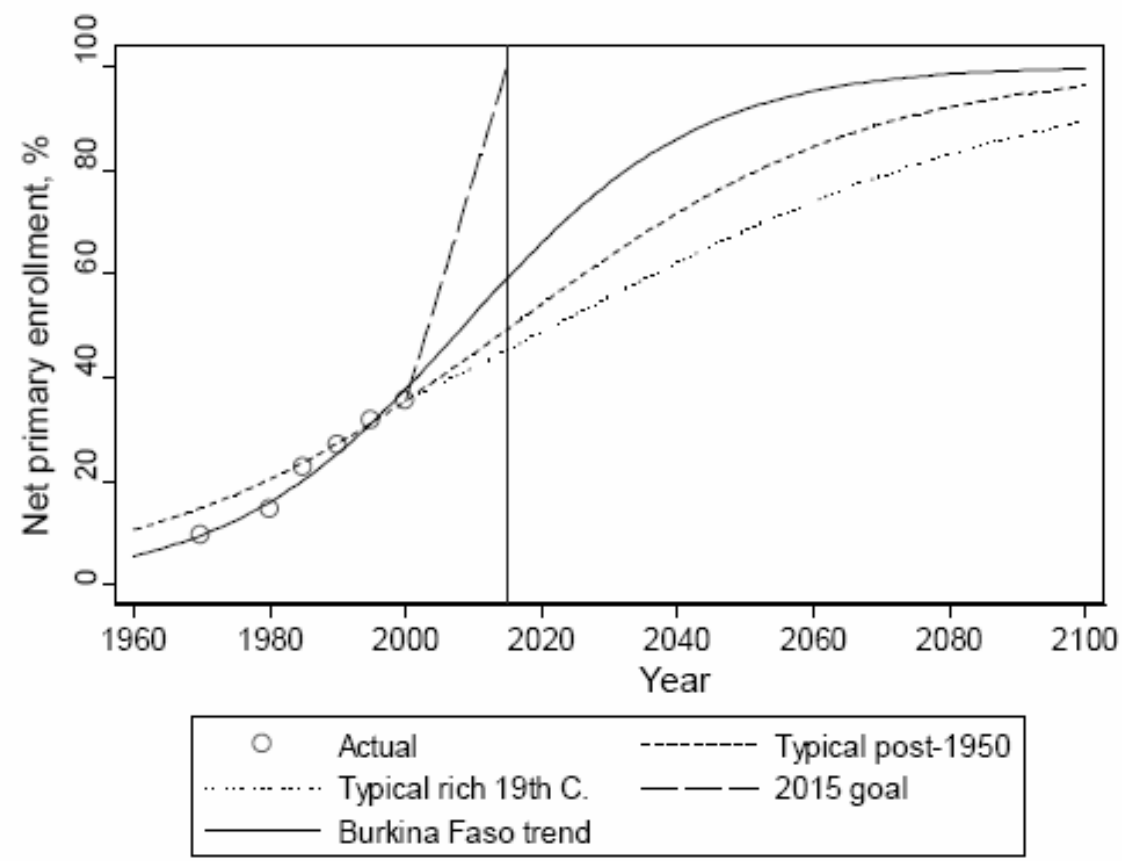

Source: Clemens, Kenny and Moss (2004). 
Chart 2.

\section{Number of Adjustment Loans to the 20 Countries with Most Adjustment Loans Over the Period 1980-1999.}

14-19 loans Niger, Zambia, Madagascar, Togo, Malawi, Mali, Mauritania, Kenya, Bolivia, Philippines, Jamaica, Bangladesh

20-25 loans Senegal, Uganda, Mexico, Morocco, Pakistan

26-30 loans Côte d'Ivoire, Ghana, Argentina

Notes: These are IMF and World Bank adjustment loans. The average number of adjustment loans for these countries over the period is 19 compared to the average of 7 for all developing countries. Out of these countries, only Bangladesh, Pakistan and Uganda achieved annual per capita growth rates above $2 \%$ over the period from their first adjustment loan to 1999

Source: Easterly (2002).

Chart 3A.

Who "Owns" IFI Policies?

\begin{tabular}{|c|c|c|c|c|c|c|c|c|c|c|}
\hline & \multicolumn{4}{|c|}{ Voting Share (\%) } & \multicolumn{5}{|c|}{ Directors } & \multirow[t]{2}{*}{ President } \\
\hline & US & Other G-7 & $\begin{array}{l}\text { Other non- } \\
\text { borrowers }\end{array}$ & $\begin{array}{c}\text { Developing } \\
\text { country } \\
\text { borrowers }\end{array}$ & US & Other G-7 & $\begin{array}{l}\text { Other non- } \\
\text { borrowers }\end{array}$ & $\begin{array}{c}\text { Developing } \\
\text { country } \\
\text { borrowers }\end{array}$ & Total & \\
\hline IMF & 17.1 & 28.2 & 16.7 & 38 & 1 & 6 & 6 & 11 & 24 & Non-borrower \\
\hline WB & 16.4 & 26.6 & 18.2 & 38.8 & 1 & 6 & 7 & 10 & 24 & Non-borrower \\
\hline IADB & 30 & 15.7 & 4.3 & 50 & 1 & 4 & 0 & 9 & 14 & Borrower \\
\hline AFDB & 6.6 & 21 & 12.4 & 60 & 1 & 4 & 1 & 12 & 18 & Borrower \\
\hline ASDB & 13 & 27.4 & 14.6 & 45 & 1 & 4 & 1 & 6 & 12 & Non-borrower \\
\hline EBRD & 10.1 & 46.5 & 30.2 & 13.2 & 1 & 6 & 12 & 4 & 23 & Non-borrower \\
\hline
\end{tabular}

Note: IMF is the International Monetary Fund, WB is the World Bank, IADB is the Inter-American Development Bank, AFDB is the African Development Bank, ASDB is the Asian Development Bank, EBRD is the European Bank for Reconstruction and Development.

Source: Birdsall (2003). 
Chart 3B.

One options: Assess the politics and institutions of pro-poor growth

\begin{tabular}{|c|c|c|}
\hline & Stakeholder Analysis & Institutional Analysis \\
\hline \multirow{3}{*}{ Trend Extrapolation } & Reforms under way & Institutional mapping \\
\hline & Decision-making style & Veto point analysis \\
\hline & Attribution of agency & Capacity assessment \\
\hline Impact Analysis & Impact on balance of power & $\begin{array}{c}\text { Impact on institutional } \\
\text { setup }\end{array}$ \\
\hline
\end{tabular}


Chart 4A.

Index of donor proliferation, 1999-2001 average

(a higher score indicates higher donor proliferation)

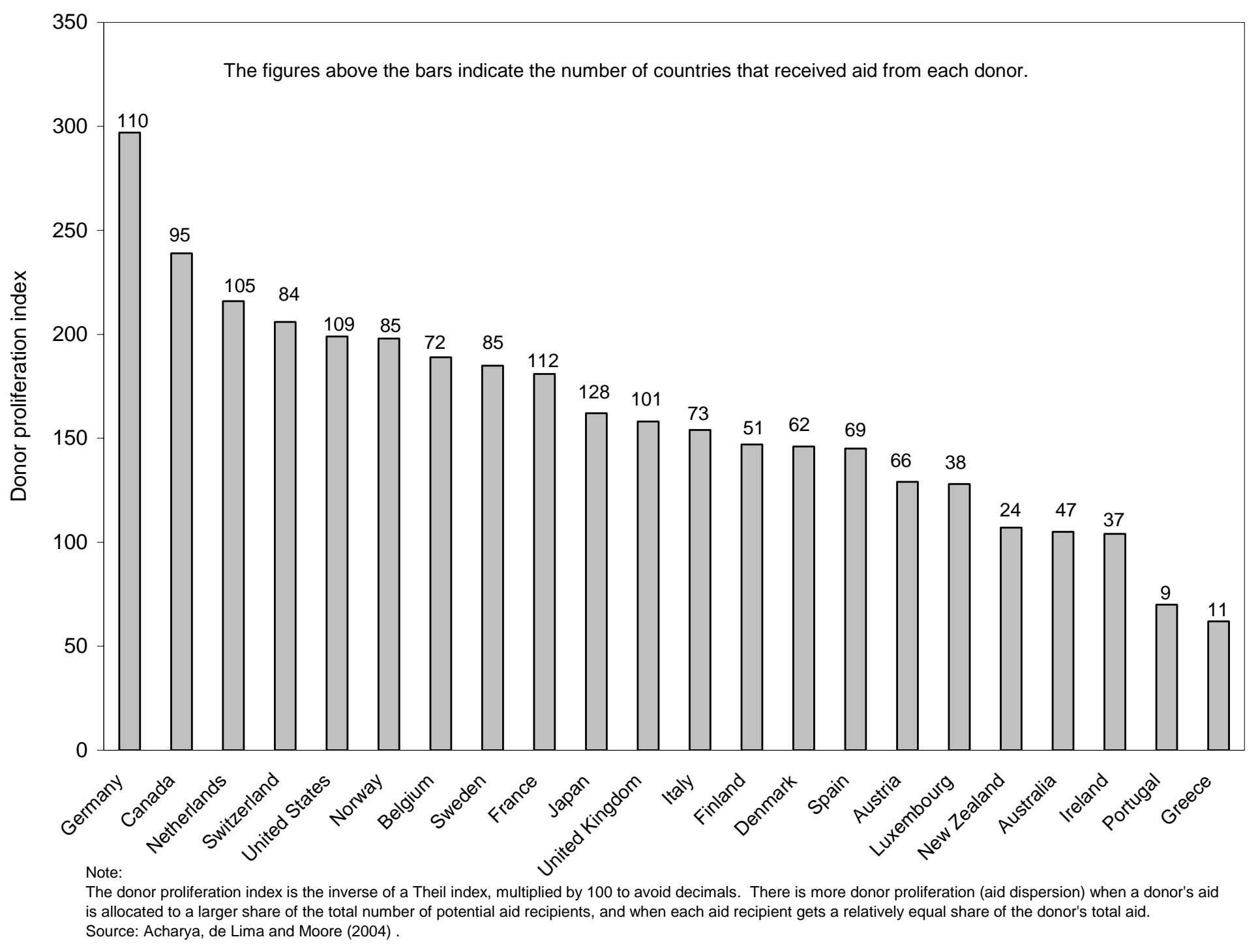


Chart 4B.

Tanzania: Average aid spending per project by donor, 2000-2002 average (thousands of US\$)

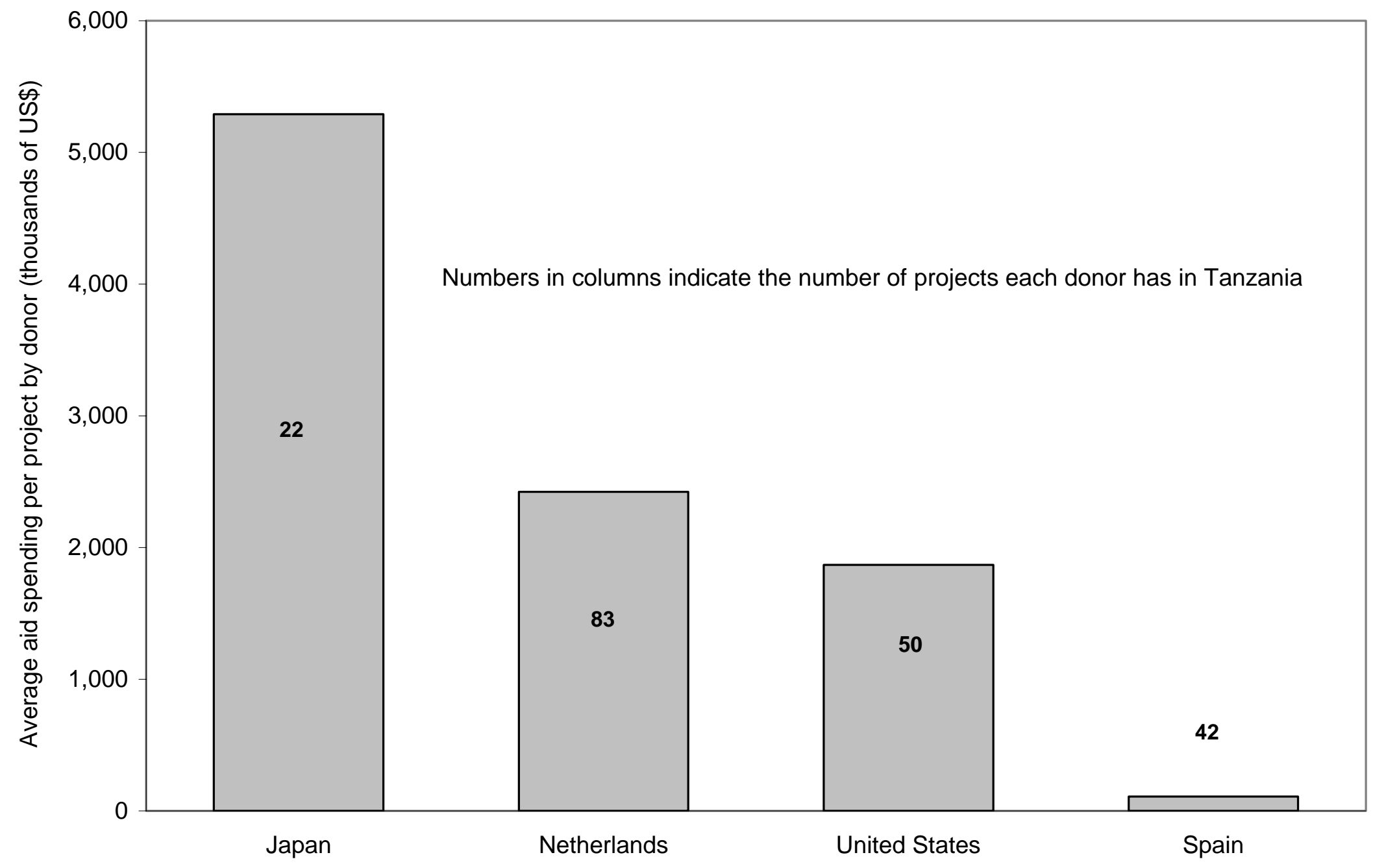

Source: Center for Global Development and Foreign Policy (2004). 
Chart 4C.

Share of each donor's total assistance allocated to multilateral institutions in 2002 (percent)

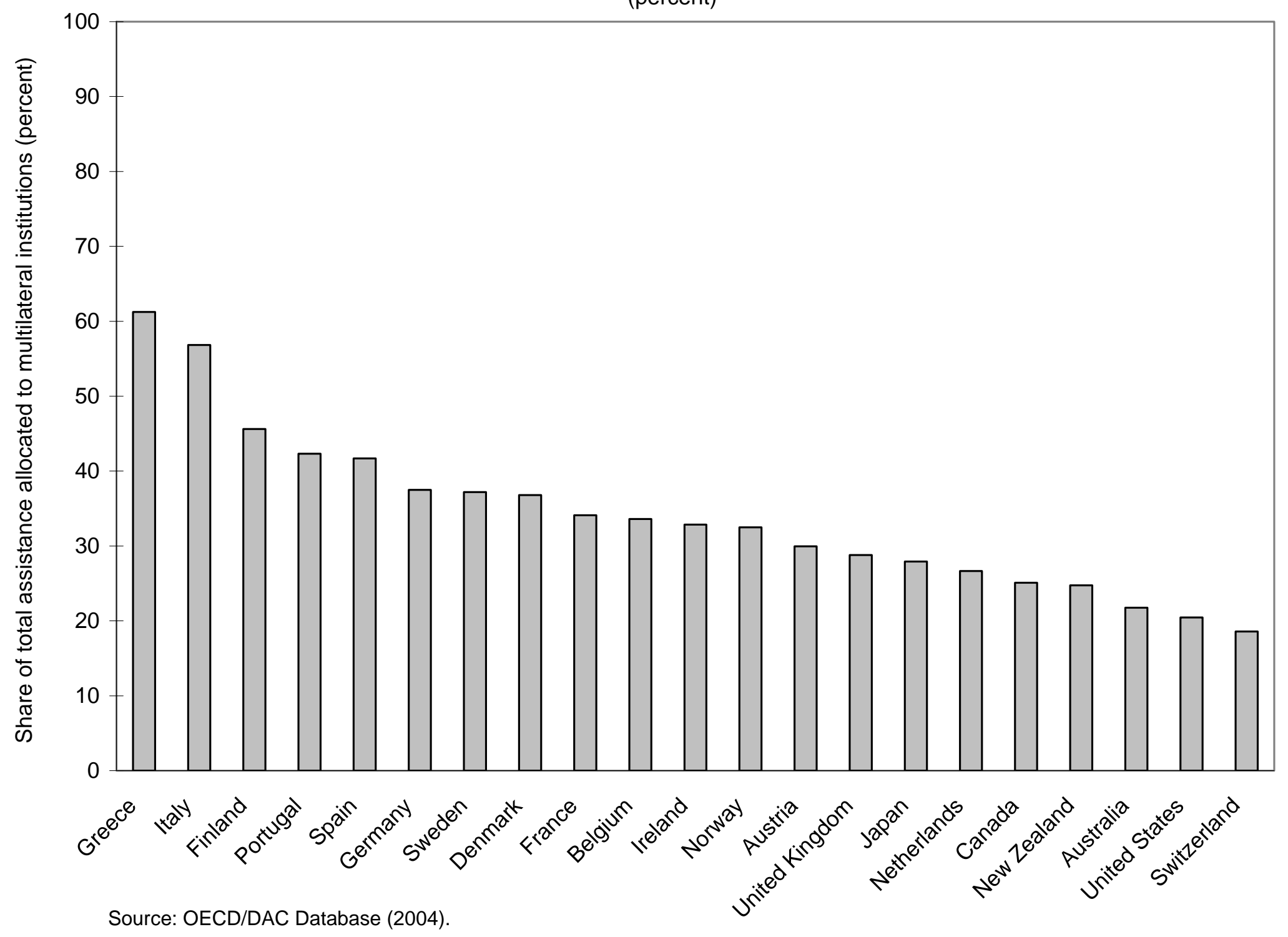


Chart 5.

Donor Commitments to Regional Programs and Projects for Selected Multilateral and Bilateral Donors in 2002

\begin{tabular}{lcc}
\hline & $\begin{array}{c}\text { Regional public goods commitments } \\
\text { by each donor }\end{array}$ & $\begin{array}{c}\text { share of total ODA commitments } \\
\text { by each donor } \\
\text { (percent) }\end{array}$ \\
\hline World Bank $^{6}$ & n/llions of US\$) & n/a \\
African Development Bank & 30 & 1.2 \\
Inter-American Development Bank $^{5}$ & 20 & 0.4 \\
Asian Development Bank $^{4}$ & 45 & 0.7 \\
European Bank for Reconstruction $^{\text {and Development }}{ }^{7}$ & 99 & 2.7 \\
UNDP $^{1}$ & 55 & 2.1 \\
WHO $^{2}$ & 138 & 7.1 \\
United States $^{3}$ & 303 & 2.4 \\
United Kingdom $^{3}$ & 98 & 2.6 \\
\hline Total $^{2}$ & 788 & 2.1 \\
\hline
\end{tabular}

Notes:

To the extent possible, commitments shown are for programs and projects that were managed by a regional organization such as the West African

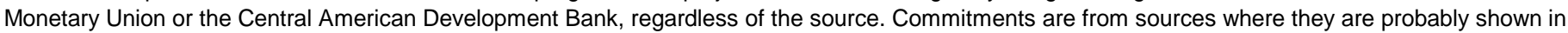
nominal terms.

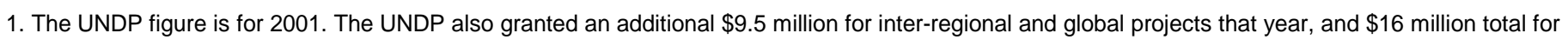
inter-country programs in 2000.

2. The WHO figure is for 1998-1999. The same amount was spent in 1996-1997.

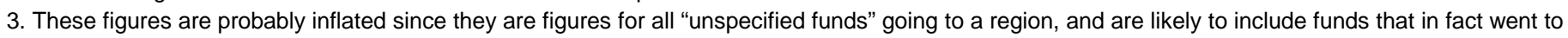
individual countries.

4. The Asian Development Bank's regional commitments reflect one project only, the Trade Finance Facilitation Program.

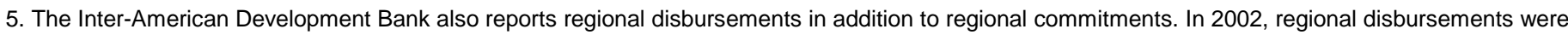
$\$ 67$ million. In the past, IDB has also made concessional loans to the Central American Bank for Economic Integration and to other subregional development banks.

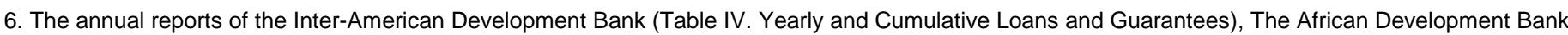
(Annex II-7 Bank Group Loan and Grant Approvals by Country), the European Bank for Reconstruction and Development (Projects signed in 2002

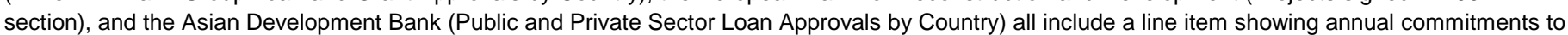
regional programs and projects. The World Bank Annual Report does not seem to provide a comparable line item.

7. This is the capital of six private equity or debt funds established to invest in or lend to private firms across two or more countries; whether these funds should be counted as multi-country programs as defined in this essay, is not entirely clear.

Source: Birdsall (2004). 